\title{
Looking for missing earthquake traces in the Ferrara-Modena plain: an update on historical seismicity
}

\author{
Viviana Castelli ${ }^{\star}$, Filippo Bernardini, Romano Camassi, Carlos H. Caracciolo, \\ Emanuela Ercolani, Luca Postpischl
}

Istituto Nazionale di Geofisica e Vulcanologia, Sezione di Bologna, Bologna, Italy

\author{
Article history \\ Received July 17, 2012; accepted August 23, 2012. \\ Subject classification: \\ Historical seismology, Surveys, measurements, and monitoring, Seismic risk, Seismological data, General or miscellaneous.
}

\section{Historical seismicity \\ according to the catalog in current use}

According to the latest issue of the Italian seismic catalogue [Rovida et al. 2011], the area most affected by the MayJune 2012 Emilia sequence [for an overview, vide Galli et al. 2012; Tertulliani et al. 2012, this volume] has a centuries-old seismic history of comparatively low magnitude events. These have been on a par with those that have occurred in the nearby Reggiano-Parmense area (where M 4.5 to M 5.5 earthquakes were comparatively frequent in the last century), although less significant than those on record in the portion of the northern Apennines that forms the southern boundary of the Pia-nura Padana (Figure 1), and a lot lower than in the most seismically active zones of the Italian peninsula. Magnitude ca. 5.5 earthquakes are known to have occurred near Ferrara (in 1346, 1561) and in the areas of Finale Emilia-Bondeno (1574, 1908, 1986), Mantua (1901) and Cento (1922). However, this picture might be incomplete, as suggested by the recent discovery of a previously unknown earthquake that occurred in 1639, whose maximum intensity was assessed as 7-8 Mercalli-Cancani-Sieberg (MCS) in Finale Emilia by Camassi et al. [2011a].

To date, the most relevant historically known local event is the so-called Ferrara earthquake of $1570\left(\mathrm{M}_{\mathrm{W}} 5.4\right)$, which was actually a complex seismic sequence that started on November 17, 1570 (when four strong shocks caused severe structural damage and partial collapses in Ferrara and its surroundings), went on with closely spaced aftershocks up to early 1572 , and then gradually petered out over the following couple of years, until March 17, 1574, when a somewhat stronger shock caused further damage in Finale Emilia [Guidoboni et al. 2007]. Another few M ca. 5.5 earthquakes have been located on the outskirts of the area affected by the 2012 sequence area. To the southeast, there was the 1624 Argenta earthquake $\left(\mathrm{M}_{\mathrm{W}} 5.4\right)$ that had a maximum intensity of 8-9 MCS in the Argenta locality [Guidoboni et al. 2007], and two similarly-sized earthquakes that occurred in $1796\left(\mathrm{M}_{\mathrm{W}}\right.$ 5.6) and $1909\left(\mathrm{M}_{\mathrm{W}}\right.$ 5.5), the latter of which might have had a deep hypocentral location, judging from its wide far field [Meloni and Molin 1987]. To the southwest, in the Carpi-Reggio area, there have been several moderately sized earthquakes, the latest of which was located near Correggio in $1996\left(\mathrm{M}_{\mathrm{W}}\right.$ 5.4).

\section{Assessing the quality of the information behind the current picture}

The studies from which the earthquake parameters of Table 1 were taken by Locati et al. [2011] are of various provenance and of variable thoroughness, and in a few cases they are relatively out of date. Most derive from Guidoboni et al. [2007], a collection that includes both advanced and preliminary studies. The studies derived from Archivio Macrosismico GNDT [1995] and ING [1998] were extremely preliminary ones; the ENEL [1985] studies were at least 27 years old and might be improved by taking into account the latest findings of local historical research (as in the case described by Camassi et al. [2011b]). In a few cases (the earthquakes of $1425,1508,1901)$, the current catalog inherited the parameters assessed for them by an earlier catalog [Postpischl 1985]; two of these earthquakes have been recently studied by Molin et al. [2008].

Looking at the general picture of local seismicity from a historian's point of view, some peculiarities become obvious. Up to the mid-1800s, for instance, there was a marked tendency for the earthquakes to cluster around Ferrara and Modena, the main towns in the area. A comparison between the seismic histories of Ferrara and Modena and those of lesser towns located midway between them, such as Carpi, Mirandola and Finale Emilia (Figure 2), shows the former to be both longer and more detailed than the latter. This suggests that the original evidence from which these seismic histories were built might have been affected by what the founding fathers 


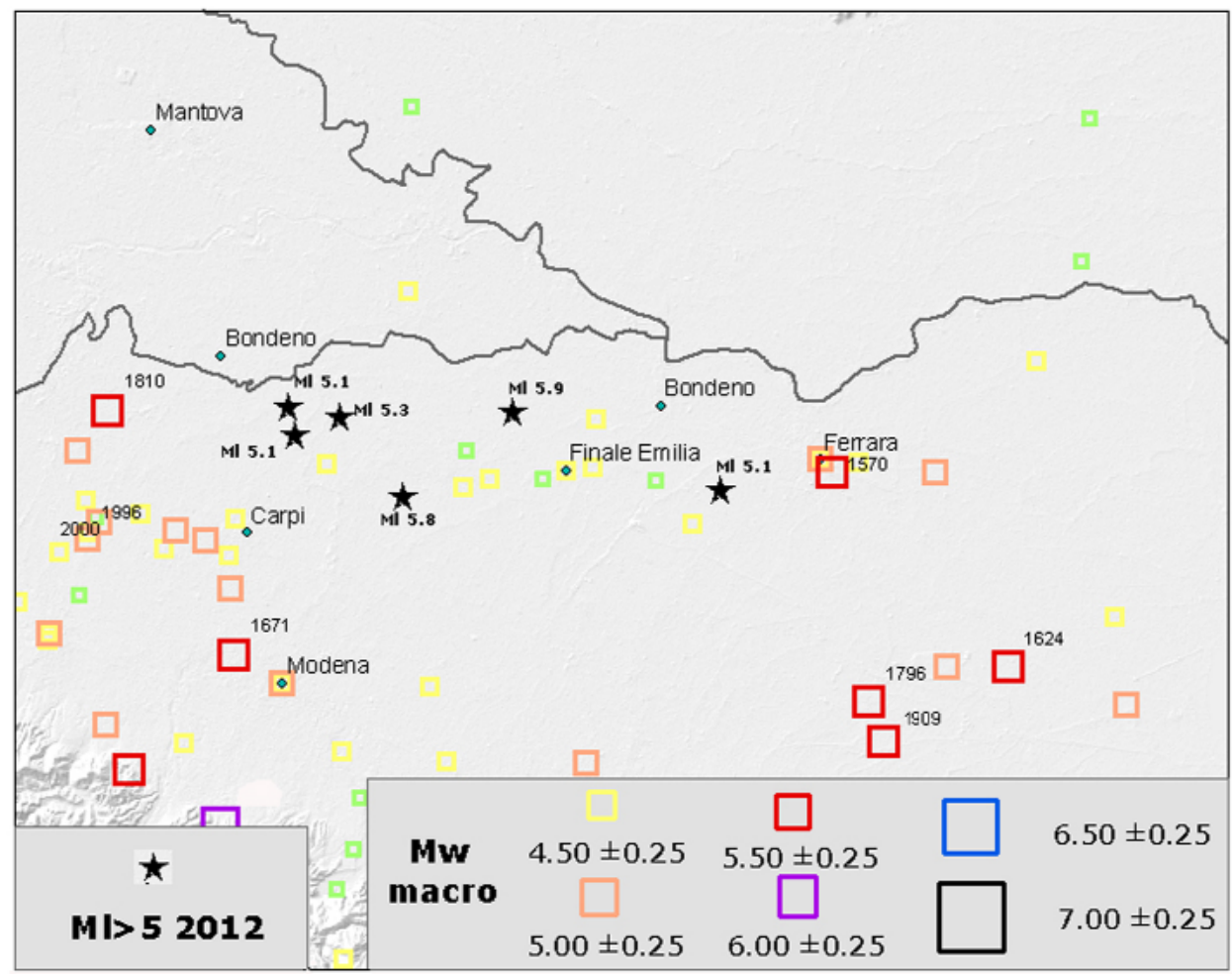

Figure 1. Seismicity of the studied area, according to Rovida et al. [2011].

of modern historical seismology called 'the urban fixation' [Vogt 1986, Vogt and Ambraseys 1991, Vogt 1994]; i.e., an inclination to focus on what happened in towns, rather than in villages and rural areas. This was particularly the case in the centuries in which literacy tended to be more widespread among townspeople than in the countryside.

It is also noticeable that earthquakes appear to have been comparatively scarcer in the 1600 s to 1700 s time window than in earlier centuries. This might reflect a real trend in the seismicity, although it might also be, partly at least, the result of choices made in the selection of historical earthquake data collected by the pre-instrumental tradition of Italian descriptive earthquake studies. This culminated in the great compilation by Baratta [1901], which is responsible, to this day, for the identification of most earthquakes that are included in the current catalog [vide Camassi et al. 2011a]. For a couple of examples, the great 18th century standard collection of medieval chronicles known as Rerum Italicarum Scriptores was undoubtedly instrumental in providing information on many earthquakes observed in Modena and Ferrara before the 1500s. Conversely, the paucity of data available in the 1600 s to 1700 s time window might be at least partly due to the chance selection of the Bologna gazette as a privileged source of earthquake information by Baratta [1901]. This gazette was one of the oldest Italian periodicals (1678-1796), and it usually published news from Rome and from a few Italian (Venice, Milan, Genoa) and European towns, but not from those at the eastern end of the Pianura Padana, such as Ferrara and Mantua [Camassi and Caracciolo 1994].

\section{A few missing local earthquakes rediscovered}

The incompleteness of the current picture of local seismicity is shown by the number of previously unknown, moderately damaging, local earthquakes, for which the information was retrieved by recent studies (Table 2 ). Three of the more interesting cases are described below.

\section{1) April 6, 1639 (Finale Emilia, Carpi?)}

A recent history of the Jewish community of Finale Emilia [Balboni 2005] quotes an authoritative local history [Frassoni 1778] as having reported an earthquake that occurred on April 6, 1639. This earthquake caused houses and chimneys to collapse in Finale, where a woman was killed. Reliable contemporary confirmation of this scenario can be found in the records of an inspection that was made by the bishop of Modena to the Finale churches in October 1639, which describes the tumbledown conditions of the Chapel of the Most Holy Annunciation "owing to the earthquake" [AAMoN 1639]. A document in the Carpi municipal archives dated as July 3, 1638, and transcribed by D'Orazi [2012] records the damage to the municipal tower of Carpi caused by "the past earthquake". Further research will be devoted to check the date of the Carpi document, and to look out for connections before it and the 1639 Finale Emilia earthquake.

\section{2) December 15, 1761 (Mirandola, Carpi, Modena)}

A collection of lives of eminent Mirandola citizens [Ceretti 1905] affirms that in 1762 one of them wrote a dissertation on earthquakes, taking his cue from "the one that occurred in Mirandola on December 15, 1761". In the after- 


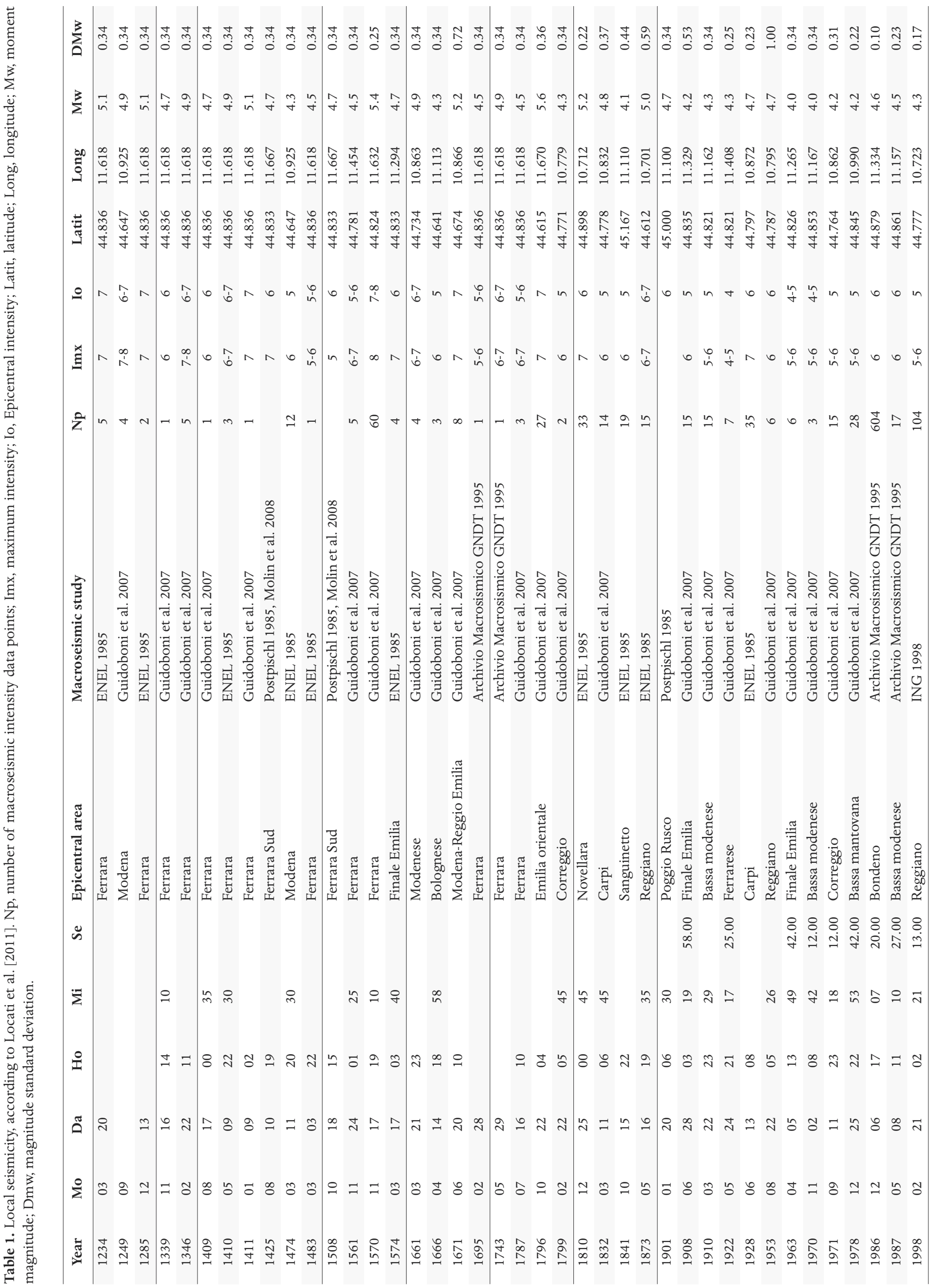




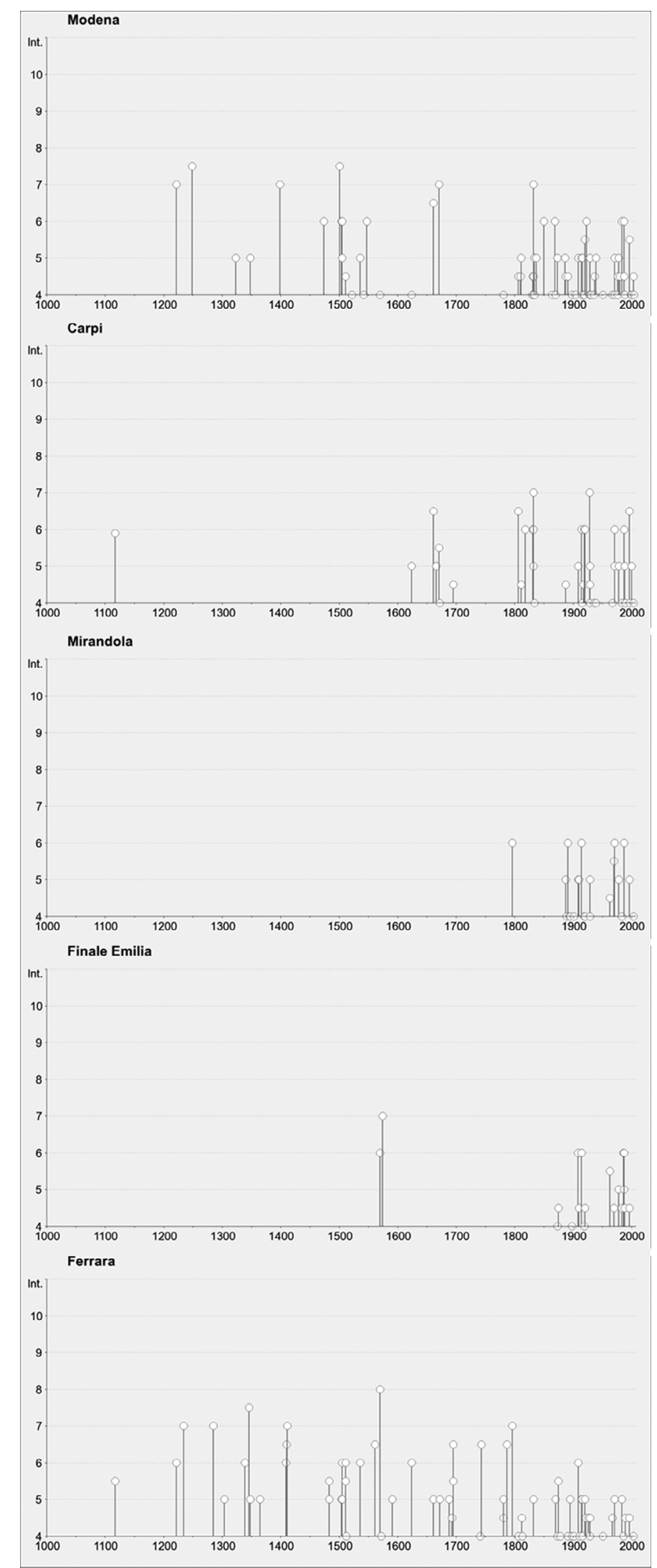

Figure 2. Comparison between seismic histories [from Locati et al. 2011].

math of the late eighteenth century Italian earthquakes, many such works were produced by supporters and opponents of the then fashionable theory of electricity as the cause of earthquakes [Castelli 2010]. Although this earthquake has been ignored by Italian seismological compila- tions and catalogs alike, it was strongly felt in Carpi [D'Orazi 2012] and more faintly in Modena [Gazzetta di Mantova 1761, Gazette de Leyde 1762]. The stir that this earthquake caused in Mirandola is attested by the large altarpiece that a prominent local family gave to the church of St Francis as a votive offering, by way of thanks for having been preserved from the earthquake [Ceretti 1890]. The painting, which is now in the Museo Civico of Mirandola and is viewable via the Emilia Romagna Heritage online catalog [IBC 2010], shows the Virgin and Child with two saints (one of which is Francis Solano, who was venerated as a special protector against earthquakes [Castelli and Camassi 2006]), and the tottering buildings of Mirandola in the background. Further research will be devoted to looking for in-situ evidence of damage (if there is any).

3) May 11, 1778 (Rovereto sulla Secchia, Concordia sulla Secchia, Carpi)

This appears to have been a seismic sequence of some duration that started with a "fearful" shock that was felt in Carpi on May 1, 1778, and continued on to August 25 of the same year [D'Orazi 2012]. The main shock on May 11, 1778, caused irreparable damage to the "most ancient and strong" tower of the Sacchella, located in the nearby hamlet of Rovereto sulla Secchia, which consequently had to be completely demolished. Fearing further collapses, the people of Rovereto and those of nearby Concordia sulla Secchia left their houses and camped in the fields until the end of the shocks. This sequence has also remained so far unknown to any Italian seismological compilation or catalog.

\section{Conclusions}

The information available on the historical seismicity of a region subjected to investigation needs to be submitted to critical scrutiny, especially in the aftermath of a strong earthquake, to test our understanding of it, and if necessary, to improve upon it. In this case, the May 2012 sequences can bid fair as the largest known to date for these areas, as the 1570 Ferrara sequence appearently occurred in a more eastward sector of the same seismogenic structure [vide Galli et al. 2012]. Our present knowledge of historical seismicity in the territory that extends from Ferrara to Finale Emilia, and from there to Mirandola and Novi di Modena, appears to be both defective and vague. However, we appear to be well on the way towards an improvement to this situation. Recent studies have retrieved the traces of several damaging earthquakes (Table 2) that occurred between the 1600s and 1700s that have so far been overlooked by the seismological literature and the parametric catalogs. The likeliest reasons for their fall into oblivion would appear to be that they failed to attract the attention of most outside contemporary witnesses because their highest macroseismic effects occurred in circumscribed, mostly rural, areas, while their attenuation 


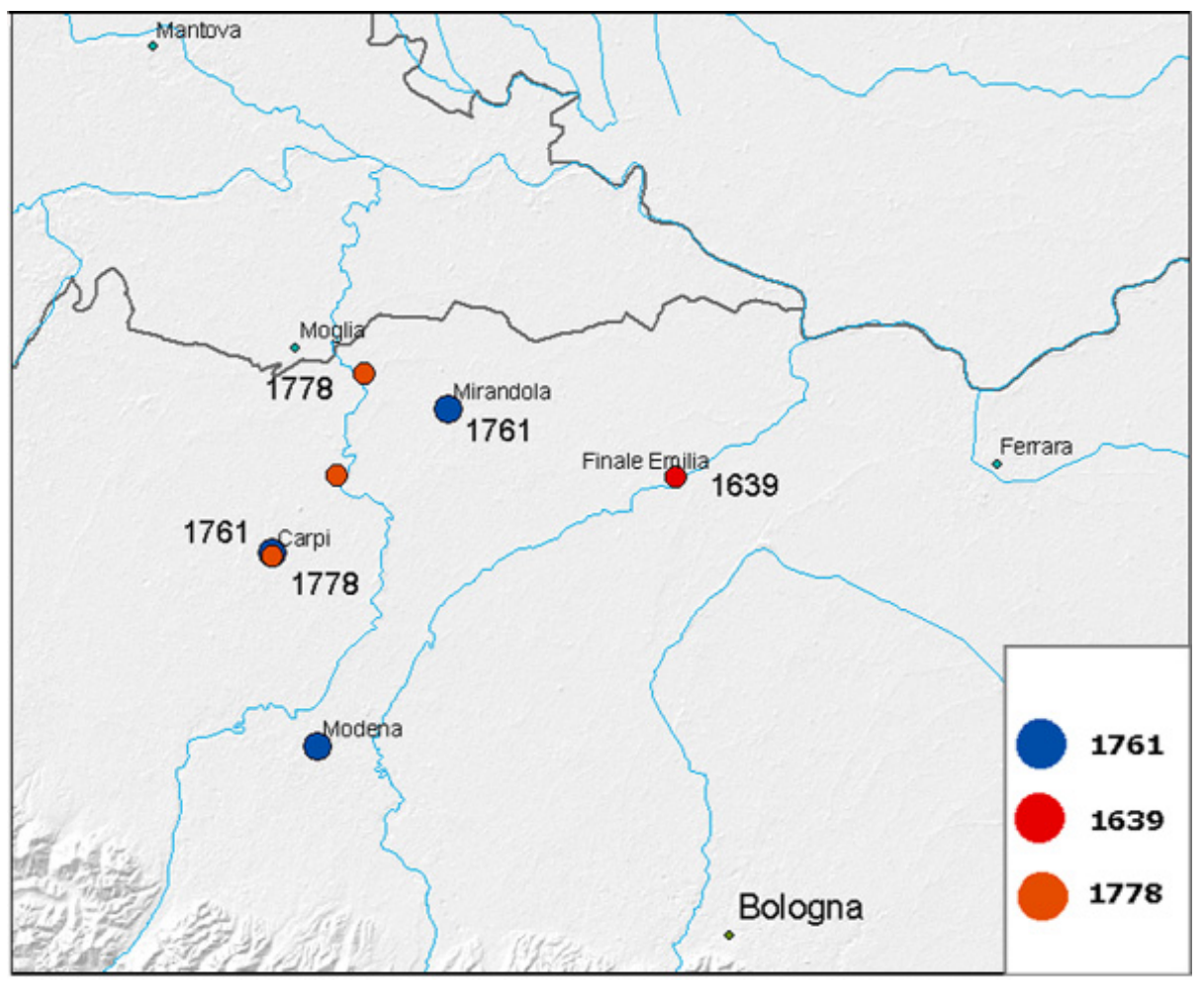

Figure 3. Locations where evidence of some missing earthquakes has been found.

\begin{tabular}{llllll}
\hline Date & \multicolumn{2}{l}{ Quoted localities } & Source / Study & Notes \\
\hline 1600 & 10 & 28 & Reggio Emilia & Camassi et al. 2011a & Strong damage in Reggio Emilia \\
1608 & 01 & 01 & Carpi, Modena, Reggio Emilia & Ongoing investigation & Probably underestimated by previous studies \\
1639 & 04 & 06 & Finale Emilia & Camassi et al. 2011a & Strong damage, one victim in Finale Emilia \\
1646 & 05 & 30 & Mantova, Cremona & Camassi et al. 2011a & Strong shaking in Mantova; felt in Cremona \\
1653 & 04 & 19 & Reggio Emilia, Colorno, Cremona, Milano & Camassi et al. 2011a & Damage in Reggio Emilia and Colorno \\
\hline 1761 & 12 & 15 & Mirandola, Carpi, Modena & Ongoing investigation & $\begin{array}{l}\text { Strong shaking in Mirandola (damage?); felt in } \\
\text { Carpi and Modena }\end{array}$ \\
1778 & 05 & 11 & $\begin{array}{l}\text { Rovereto sulla Secchia, Concordia sulla } \\
\text { Secchia, Carpi }\end{array}$ & Ongoing investigation & Heavily damaged tower in Rovereto \\
\hline
\end{tabular}

Table 2. Traces of missing local earthquakes retrieved by recent studies.

was so strong that they were not felt in any major nearby town (e.g., Bologna, Ferrara, Modena or Mantua). Through the clues retrieved so far, the authors of this paper are about to start an $a d-h o c$ quest for earthquake information in local archives and libraries.

Acknowledgements. We thank Paolo Galli and an anonymous reviewer for their thoughtful suggestions.

\section{References}

AAMoNo (Archivio Arcidiocesi di Modena-Nonantola) (1639). Visite Pastorali, 24, c. 33v.

Archivio Macrosismico GNDT (1995). Studi preliminari di terremoti attraverso i repertori sismologici, Archivio macrosismico del GNDT, Milano; Macroseismic Data Points available online: http:/ / emidius.mi.ingv.it/DOM/ consultazione.html
Balboni, M.P. (2005). Gli ebrei del Finale nel Cinquecento e nel Seicento, Firenze, 234 pp.

Baratta, M. (1901). I terremoti d'Italia: saggio di storia, geografia e bibliografia sismica italiana, Torino, $950 \mathrm{pp}$.

Camassi, R., and C. Caracciolo (1994). The gazette "Bologna": an observer of European natural events in the early 18th century, In: P. Albini and A. Moroni (eds.), Materials of the CEC project Review of Historical Seismicity in Europe, 2, Milan, 153-162.

Camassi, R., V. Castelli, D. Molin, F. Bernardini, C.H. Caracciolo, E. Ercolani and L. Postpischl (2011a). Materiali per un catalogo dei terremoti italiani: eventi sconosciuti, rivalutati o riscoperti, Quaderni di Geofisica, 96, 50+387 pp.; available online: http:/ / istituto.ingv.it/l-ingv/ produzionescientifica / quaderni-di-geofisica

Camassi, R., C.H. Caracciolo, V. Castelli and D. Slejko (2011b). 
The 1511 eastern Alps earthquakes: a critical update and comparison of existing macroseismic datasets, J. Seismol., 15, 191-213.

Castelli, V., and R. Camassi (2006). A che santo votarsi. L'influsso dei grandi terremoti del 1703 sulla cultura popolare, In: R. Colapietra, G. Marinangeli and P. Muzi (eds.), Settecento abruzzese. Eventi sismici, mutamenti economico-sociali e ricerca storiografica, Libreria Colacchi, L'Aquila, 107-130.

Castelli, V. (2010). Electric Soldani. Fashionable earthquake theories in late eighteenth century Italy, Journal of the Siena Academy of Sciences, 2, 10-12.

Ceretti, F. (1890). Delle chiese, dei conventi e delle confraternite della Mirandola, In: Memorie storiche della città e dell'antico ducato della Mirandola, 8, Mirandola, 240 pp.

Ceretti, F. (1905). Sulle antiche accademie di Mirandola. Notizie, In: Biografie mirandolesi, 4, Mirandola, 324 pp.

D'Orazi, M. (2012). Terremoti avvenuti o percepiti a Carpi in base alle cronache storiche locali, dalle ricerche di Gianfranco Guaitoli e Luciana Nora (Barabba Elettrolibri); available online: http: / / barabba-log.blogspot.it/2012/06/ barabba-elettrolibri-terremoti-avvenuti.html

ENEL (1985). Studi e indagini per l'accertamento della idoneità tecnica delle aree suscettibili di insediamento di impianti nucleari per le Regioni Piemonte, Lombardia e Puglia: indagini di sismica storica, Rapporti tecnici predisposti da ISMES-SGA, Roma; Macroseismic Data Points, available online: http:/ / emidius.mi.ingv.it/DOM / consultazione.html

Frassoni, C. (1778). Memorie del Finale di Lombardia, Modena; anastatic reprint, Forni, Sala Bolognese, 1974.

Galli, P., S. Castenetto and E. Peronace (2012). May 2012 Emilia earthquakes $\left(\mathrm{M}_{\mathrm{W}} 6\right.$, northern Italy): macroseismic effects distribution and seismotectonic implications, Alpine and Mediterranean Quaternary, 25, 105-123, in press; available online: http: / amq.aiqua.it

Gazette de Leyde (1762). January 15, Nr. 5.

Gazzetta di Mantova (1761). December 25, Nr. 52.

Guidoboni, E., G. Ferrari, D. Mariotti, A. Comastri, G. Tarabusi and G. Valensise (2007). CFTI4Med, Catalogue of Strong Earthquakes in Italy (461 B.C.-1997) and the Mediterranean Area (760 B.C.-1500), INGV-SGA; available online: http: / / storing.ingv.it/cfti4med/

IBC (Istituto per i Beni Artistici, Culturali e Naturali della Regione Emilia-Romagna) (2010). Emilia Romagna Heritage online catalog, File OA Nr. 00000130: Madonna con Bambino in gloria con san Felice Cappuccino e san Francesco Solano, Mirandola, Museo Civico; available online at http: / / bbcc.ibc.regione.emilia-romagna.it/samira/ v2fe/loadcard.do?id_card $=141922 \&$ force $=1$

ING (Istituto Nazionale di Geofisica) (1998). Bollettino macrosismico mensile.

Locati, M., R. Camassi and M. Stucchi, eds. (2011). DBMI11,
Database Macrosismico Italiano 2011, Milano/Bologna; available online: http: / / emidius.mi.ingv.it/DBMI11

Meloni, F., and D. Molin (1987). Il terremoto padano del 13 gennaio 1909, In: Atti del $6^{\circ}$ Convegno Annuale del GNGTS, Roma 1, 269-294.

Molin, D., F. Bernardini, R. Camassi, C.H. Caracciolo, V. Castelli, E. Ercolani and L. Postpischl (2008). Materiali per un catalogo dei terremoti italiani: revisione della sismicità minore del territorio nazionale, Quaderni di Geofisica, 57, 75 pp. + CD-ROM; available online: http: / /istituto.ingv. it/1-ingv/produzione-scientifica / quaderni-di-geofisica

Postpischl, D. (1985). Catalogo dei terremoti italiani dall'anno 1000 al 1980, Quaderni de "La Ricerca scientifica", 114 (2B), CNR, Roma, 239 pp.

Rovida, A., R. Camassi, P. Gasperini and M. Stucchi, eds. (2011). CPTI11, Parametric Catalogue of Italian Earthquakes, 2011 version, Milano, Bologna; availabe online: http: / / emidius.mi.ingv.it/CPTI

Tertulliani, A., L. Arcoraci, M. Berardi, F. Bernardini, B. Brizuela, C. Castellano, S. Del Mese, E. Ercolani, L. Graziani, A. Maramai, A. Rossi, M. Sbarra and M. Vecchi (2012). The Emilia 2012 sequence: a macroseismic survey, Annals of Geophysics, 55 (4); doi:10.4401/ag-6140.

Vogt, J. (1986). Le tremblement de terre du 25 mars 1588 aux confins de l'Anjou et de la Bretagne, Norois, 130, 241246, available online: http: / / www.persee.fr/web/ revues / home/prescript/article/noroi_0029-182x_1986_num_ 130_1_4313

Vogt, J., and N.N. Ambraseys (1991). Matériaux relatifs à la sismicité de l'Algérie occidentale au cours de la deuxième moitié du XIXe et au début du XXe siècle, Méditerranée, 74 (4), 39-45; available online: http: / / www.persee.fr/web / revues/home/prescript/article/medit_0025-8296_1991 _num_74_4_2736

Vogt, J. (1994). Progrès de la connaissance de la macrosismicité de l'Alsace, In: P. Albini and A. Moroni (eds.), Materials of CEC Project Review of Historical Seismicity in Europe, CNR, Milano, 2, 254 pp.; available online: http:/ / emidius.mi.ingv.it/RHISE/ii_7vog/ii_7vog.html

\footnotetext{
${ }^{\star}$ Corresponding author: Viviana Castelli, Istituto Nazionale di Geofisica e Vulcanologia, Sezione di Bologna, c/o Sede di Ancona, Ancona, Italy; email: viviana.castelli@bo.ingv.it.

C) 2012 by the Istituto Nazionale di Geofisica e Vulcanologia. All rights reserved.
} 